University of Nebraska - Lincoln

DigitalCommons@University of Nebraska - Lincoln

Agronomy \& Horticulture -- Faculty Publications

Agronomy and Horticulture Department

2010

\title{
Effect of Nitrogen Addition and Weed Interference on Soil Nitrogen and Corn Nitrogen Nutrition
}

John L. Lindquist

University of Nebraska-Lincoln, jlindquist1@unl.edu

Sean P. Evans

University of Nebraska-Lincoln

Charles A. Shapiro

University of Nebraska-Lincoln, cshapiro1@unl.edu

Stevan Z. Knezevic

University of Nebraska-Lincoln, sknezevic2@unl.edu

Follow this and additional works at: https://digitalcommons.unl.edu/agronomyfacpub

Part of the Plant Sciences Commons

Lindquist, John L.; Evans, Sean P.; Shapiro, Charles A.; and Knezevic, Stevan Z., "Effect of Nitrogen Addition and Weed Interference on Soil Nitrogen and Corn Nitrogen Nutrition" (2010). Agronomy \& Horticulture -- Faculty Publications. 420.

https://digitalcommons.unl.edu/agronomyfacpub/420

This Article is brought to you for free and open access by the Agronomy and Horticulture Department at DigitalCommons@University of Nebraska - Lincoln. It has been accepted for inclusion in Agronomy \& Horticulture -Faculty Publications by an authorized administrator of DigitalCommons@University of Nebraska - Lincoln. 


\title{
Effect of Nitrogen Addition and Weed Interference on Soil Nitrogen and Corn Nitrogen Nutrition
}

\author{
John L. Lindquist, Sean P. Evans, Charles A. Shapiro, and Stevan Z. Knezevic*
}

\begin{abstract}
Weeds cause crop loss indirectly by reducing the quantity of resources available for growth. Quantifying the effects of weed interference on nitrogen $(\mathrm{N})$ supply, crop growth, and $\mathrm{N}$ nutrition may assist in making both $\mathrm{N}$ and weed management decisions. Experiments were conducted to quantify the effect of $\mathrm{N}$ addition and weed interference on soil nitrate- $\mathrm{N}\left(\mathrm{NO}_{3}-\right.$ $\mathrm{N}$ ) over time and the dependence of corn growth on $\mathrm{NO}_{3}-\mathrm{N}$ availability, determine the corn $\mathrm{N}$ nutrition index (NNI) at anthesis, and evaluate if relative chlorophyll content can be utilized as a reliable predictor of NNI. Urea was applied at 0 , 60 , and $120 \mathrm{~kg} \mathrm{~N} /$ ha to establish N treatments. Season-long weedy, weed-free, and five weed interference treatments were established by delaying weed control from time of crop planting to the V3, V6, V9, V15, or R1 stages of corn development. Soil $\mathrm{NO}_{3}-\mathrm{N}$ ranged from $20 \mathrm{~kg} \mathrm{~N} /$ ha without $\mathrm{N}$ addition to $98 \mathrm{~kg} \mathrm{~N} / \mathrm{ha}$ with $120 \mathrm{~kg} \mathrm{~N} / \mathrm{ha}$ added early in the season, but crop and weed growth reduced soil $\mathrm{NO}_{3}-\mathrm{N}$ to $10 \mathrm{~kg} \mathrm{~N} /$ ha by corn anthesis. Weed presence reduced soil $\mathrm{NO}_{3}-\mathrm{N}$ by up to $50 \%$. Average available $\mathrm{NO}_{3}-\mathrm{N}$ explained 29 to $40 \%$ of the variation in corn shoot mass at maturity. Weed interference reduced corn biomass and NNI by 24 to $69 \%$. Lack of N also reduced corn NNI by 13 to $46 \%$, but reduced corn biomass by only 11 to $23 \%$. Nondestructive measures of relative chlorophyll content predicted corn NNI with 65 to $85 \%$ accuracy. Although weed competition for factors other than $\mathrm{N}$ may be the major contributor to corn biomass reduction, the chlorophyll meter was a useful diagnostic tool for assessing the overall negative effects of weeds on corn productivity. Further research could develop management practices to guide supplemental N applications in response to weed competition.
\end{abstract}

Nomenclature: Corn, Zea mays L. 'DK589RR'.

Key words: Duration of weed interference, nitrogen uptake, resource acquisition, interplant competition, nitrogen nutrition index, chlorophyll.

La maleza causa pérdida indirecta del cultivo porque reduce la cantidad de recursos disponibles para su crecimiento. La cuantificación de los efectos de la interferencia de la maleza en el suministro de nitrógeno $(\mathrm{N})$, crecimiento de cultivo y en la nutrición, es importante para la toma de decisiones relativas a la administración del $\mathrm{N}$ y al manejo de la maleza. Se realizaron experimentos para cuantificar los efectos de la administración de nitrógeno e interferencia de la maleza en el nitrato-N del suelo $\left(\mathrm{NO}_{3}-\mathrm{N}\right)$ al paso del tiempo y la dependencia del crecimiento de maíz con disponibilidad de $\mathrm{NO}_{3}-\mathrm{N}$, para determinar el índice de nutrición del maíz (NN1) al espigamiento, y para evaluar si el contenido de clorofila relativa puede ser utilizada como un estimador confiable de (NN1). Urea fue aplicada a 0, 60 y $120 \mathrm{~kg} \mathrm{~N} / \mathrm{ha}$ para establecer tratamientos de N. Se establecieron siete tratamientos: el primero, con largos períodos de abundante maleza, otro libre de maleza y cinco tratamientos con diferentes interferencias de maleza, a través de retrasar el control de la misma, cuando el maíz alcanzó las etapas V3, V6, V9, V15 y R1. El nitrato en el suelo se encontró en cantidades de $20 \mathrm{~kg} / \mathrm{ha}$ sin adición de N. Cuando se aplicó $120 \mathrm{~kg}$ de N/ha, se registró una cantidad de $98 \mathrm{~kg} / \mathrm{ha}$ de nitratos, al principio de la estación. Sin embargo, el crecimiento de la maleza y del cultivo redujeron el nitrato del suelo a $10 \mathrm{~kg} / \mathrm{ha}$ hasta la antesis. La presencia de maleza, disminuyó el nitrato del suelo hasta un 50\%. El promedio de $\mathrm{NO}_{3}-\mathrm{N}$ disponible explicó del 29 al $40 \%$ de la variación del crecimiento de los brotes del maíz, en la etapa de maduración. La interferencia de la maleza redujo la biomasa del maíz y del NN1 entre 24 y 69\%. La falta de N redujo el NN1 del maíz de un 13 a un 46\%, pero disminuyó la biomasa del maíz solamente del 11 al 23\%. Las medidas no destructivas del contenido relativo de clorofila, estimaron el NN1 de maíz con un 65 a $80 \%$ de certeza. Mientras que la competencia de maleza para factores diferentes al $\mathrm{N}$ puede ser el factor más importante en la reducción de la biomasa del maíz; el medidor de clorofila fue una herramienta útil de diagnóstico para evaluar sobretodo los efectos negativos de la maleza en el rendimiento. Futuras investigaciones deben de desarrollar guías prácticas de manejo en aplicaciones suplementarias de $\mathrm{N}$, en respuesta a la competencia de la maleza.

Historically, crop and weed interference research has focused on the phenomenon of competition (i.e., the existence of or the intensity of competition in various environments). Tilman (1990) argued that the problem with these approaches is that they are useful only as a posteriori descriptors that

\footnotetext{
DOI: 10.1614/WT-09-070.1

* Associate Professor, Department of Agronomy and Horticulture, University of Nebraska, Lincoln, NE 68583; Former Graduate Student, Monsanto Company, Jerseyville, IL 62052; Professor and Associate Professor, Haskell Agricultural Laboratory, University of Nebraska, Concord, NE 68728. Corresponding author’s E-mail: jlindquist1@unl.edu
}

demonstrate the existence of competition and have little predictive power. He suggested that study of the mechanisms of competition will provide potentially much more predictive ability. Goldberg (1990) argued that most interactions between plants occur through some intermediary such as plant essential resources. In other words, weeds (with the exception of parasitic weeds) do not generally have a direct effect on the physiological status of a crop plant. However, both the weed and the crop have a direct effect on the resources available in their immediate environment as well as unique responses to the quantity of resources available within 
that environment (Lindquist 2001). Therefore, evidence of weed competition for a resource such as soil nitrogen $(\mathrm{N})$ must include documentation of depletion of $\mathrm{N}$ associated with the presence of weeds and the dependence of crop growth on N availability (Shainsky and Radosevich 1992). Because the outcome of crop-weed competition for $\mathrm{N}$ is driven by the physiological mechanisms that regulate the effect of each species on soil $\mathrm{N}$ and their response to the quantity of $\mathrm{N}$ available to the plant (Lindquist 2001; Lindquist et al. 2007), it is also important to understand how varying $\mathrm{N}$ supply affects crop $\mathrm{N}$ nutrition.

In aerated soils, $\mathrm{N}$ is acquired by plants primarily through the absorption of nitrate $\left(\mathrm{NO}_{3}\right.$; Devienne-Barret et al. 2000), the availability of which is subject to biotic and abiotic processes affecting the total pool of soil N. Consequently, the concentration of $\mathrm{NO}_{3}$ in the soil solution may not be adequate to meet immediate growth requirements. Inadequate supply of soil $\mathrm{N}$ is a major factor contributing to reduction in crop growth and grain yield (Below et al. 1981; Greenwood 1976; Hanway 1962; Sinclair and De Wit 1975; Sinclair and Muchow 1995). Diagnosing N deficiency may be of great practical value in determining the quantity of $\mathrm{N}$ required to maintain optimum growth and yield while minimizing the risk of $\mathrm{N}$ loss to ground and surface waters (Ziadi et al. 2008b).

One plant-based approach to diagnosing $\mathrm{N}$ deficiency utilizes the concept of a critical $\mathrm{N}$ concentration $\left(\% \mathrm{~N}_{\mathrm{c}}\right)$, or the minimum $\% \mathrm{~N}$ in shoots required to produce the maximum crop growth at any given time during the growing season (Plenet and Lemaire 2000). This concept was advanced with the use of considerable ecophysiological theory by Lemaire (1997) and colleagues and is based on the allometric relationship between $\% \mathrm{~N}$ and total aboveground biomass. The critical $\mathrm{N}$ concentration was defined for corn by

$$
\% \mathrm{~N}_{\mathrm{c}}=3.4(W)^{-0.37},
$$

where $W$ is total shoot biomass ranging from 1 to $22 \mathrm{Mg} / \mathrm{ha}$ (Plenet and Lemaire 2000).

The concept of the critical $\mathrm{N}$ concentration-crop shoot mass ( W) relationship is important because it links $\mathrm{N}$ uptake to tissue $\mathrm{N}$ concentration, crop growth rate, and soil nitrate availability (Devienne-Barrett et al. 2000; Gastal and Lemaire 2002; Lemaire et al. 2008). The concept also is useful from a management standpoint because it can be used to define a $\mathrm{N}$ nutrition index (NNI) as the ratio of actual $\mathrm{N}$ concentration $\left(\% \mathrm{~N}_{\mathrm{a}}\right)$ and $\% \mathrm{~N}_{\mathrm{c}}$ in shoot tissue at any given time, which is a reliable indicator of the level of corn $\mathrm{N}$ stress during the growing season (Ziadi et al. 2008a). The concept may be useful in weed management because if weed competition reduces the quantity of $\mathrm{N}$ available for crop growth, it can be expected that crop $\mathrm{N}$ nutritional status will be negatively affected. Therefore, the NNI may be a useful diagnostic not only of the need for supplemental $\mathrm{N}$, but also of the intensity of weed impact on the crop.

Use of the NNI as a practical in-season diagnostic tool is problematic because measurement of the NNI requires destructive sampling of shoot tissues to determine total aboveground biomass followed by drying and grinding of tissues and quantifying the total $\mathrm{N}$ concentration in those tissues. A simple nondestructive diagnostic tool would be considerably more convenient for practitioners. Several authors have shown that measured NNI was highly correlated to the normalized index obtained from measurements made with the SPAD 502 chlorophyll meter, which provides a rapid, nondestructive estimate of relative leaf chlorophyll content (Debaeke et al. 2006; Ziadi et al. 2008b). If the SPAD meter can be used to predict NNI reliably, it may also be a useful tool for assessing the relative impact of weeds on crops.

The objectives of this research were to determine the effect of $\mathrm{N}$ addition and weed interference on (1) soil nitrate content over time, (2) the dependence of corn growth on available soil $\mathrm{N}$, and (3) corn $\mathrm{N}$ nutrition status, and to evaluate if a simple measure of relative chlorophyll content with the use of the SPAD meter can be utilized as a reliable predictor of NNI.

\section{Materials and Methods}

Site Description. Field experiments were conducted in 1999 and 2000 at the Haskell Agricultural Laboratory (HAL) near Concord, NE, and the University of Nebraska Agricultural Research and Development Center (ARDC) near Mead, NE. Experiments were located in adjacent fields each year at each location that were in a corn-soybean rotation. Soil types were a Kennebec series silty clay loam (fine-silty, mixed, mesic Cumulic Hapludolls) with 0 to $2 \%$ slopes at HAL and a Sharpsburg silty clay loam (fine, smectitic, mesic Typic Argiudolls) with 0 to $2 \%$ slopes with inclusions of Butler silty clay loam (fine, smectitic, mesic Abruptic Argiaquaolls) with 0 to $2 \%$ slopes at the ARDC. Soil chemical properties averaged over years for each site were $\mathrm{pH} 6.5,39 \mathrm{mg} / \mathrm{g}$ soil organic carbon, $49 \mathrm{mg} / \mathrm{kg}$ Bray P1, $471 \mathrm{mg} / \mathrm{kg}$ extractable $\mathrm{K}$ at HAL; and $\mathrm{pH}$ 6.6, $28 \mathrm{mg} / \mathrm{g}$ soil organic carbon, $18 \mathrm{mg} / \mathrm{kg}$ Bray P1, $330 \mathrm{mg} / \mathrm{kg}$ extractable $\mathrm{K}$ at the ARDC. Weed interference was obtained by a naturally occurring weed population typical of conventional corn cropping systems of eastern Nebraska. Total weed densities at the R1 stage of corn ranged from 80 to 364 plants $/ \mathrm{m}^{2}$, depending on year and location. Dominant weed species included velvetleaf (Abutilon theophrasti Medic.), Amaranthus species, and Setaria species at HAL in 1999 and 2000 and at the ARDC in 2000. Pennsylvania smartweed (Polygonum pensylvanicum L.) was an additional dominant weed at the ARDC in 1999 (Evans et al. 2003b).

Experimental Design and Procedures. Prior to crop planting, surface soil samples (0 to $0.15 \mathrm{~m}$ ) were collected at each site to determine soil organic carbon content, available phosphorous (P) with the Bray and Kurtz No. 1 method (Bray and Kurtz 1945), and potassium (K) by ammonium acetate extraction (Brown and Warncke 1988). Each replication was sampled with a hand probe; 10 soil cores were composited and air dried before analysis. Additional samples from 0.15 to $0.30 \mathrm{~m}$ and 0.3 to $1.2 \mathrm{~m}$ were collected for nitrate determination. Nitrate-nitrogen $\left(\mathrm{NO}_{3}-\mathrm{N}\right)$ was determined with the use of the cadmium reduction method (Gelderman and Beegle 1998) from a depth of 0 to $1.2 \mathrm{~m}$ and converted to a mass basis ( $\mathrm{kg} \mathrm{N} / \mathrm{ha}$ ) assuming an average soil bulk density of $1.25 \mathrm{~g} / \mathrm{cm}^{3}$. Fertilizer applications reflected 
the University of Nebraska's recommendations for corn (Hergert et al. 1995). Triple super-phosphate fertilizer $\left(460 \mathrm{mg} / \mathrm{g}_{2} \mathrm{O}_{5}\right)$ was broadcast at a rate equivalent to $26 \mathrm{~kg} \mathrm{P} / \mathrm{ha}$ in each year at the ARDC location $2 \mathrm{wk}$ prior to planting. Urea $(460 \mathrm{mg} / \mathrm{g}$ elemental $\mathrm{N})$ was broadcast at the time of or up to $10 \mathrm{~d}$ prior to planting to establish desired $\mathrm{N}$ application rates of 0,60 , or $120 \mathrm{~kg} \mathrm{~N} /$ ha with the use of a ground-driven fertilizer drop spreader. ${ }^{1}$ The highest $\mathrm{N}$ rate was determined with average soil $\mathrm{NO}_{3}-\mathrm{N}$ and a corn grain yield goal of $8 \mathrm{Mg} / \mathrm{ha}$ (Hergert et al. 1995).

Primary tillage consisted of fall chisel plow at the ARDC and spring disk at HAL. Immediately following fertilizer application, one or more secondary tillage operations were performed on all fields to incorporate fertilizer and prepare the seedbed for planting. A glyphosate-resistant corn cultivar 'DK589RR' ' was planted in rows spaced $0.76 \mathrm{~m}$ apart on May 25 and May 13, 1999, and May 11 and May 2, 2000, at HAL and ARDC, respectively (Evans et al. 2003a).

Experiments were established as a factorial arrangement of treatments in a split-plot block design with nitrogen application rate $(0,60$, or $120 \mathrm{~kg} \mathrm{~N} / \mathrm{ha})$ as the main plot and duration of weed control as the subplot. Subplot experimental units consisted of six corn rows $12.2 \mathrm{~m}$ in length. Main plots were arranged in randomized complete blocks with four replications at each location. For each subplot, treatments were imposed to represent increasing duration of weed interference. These treatments were established by delaying weed control from the time of crop planting up to predetermined crop growth stages (weedy up to V3, V6, V9, V15, and R1), at which weed control was initiated and maintained for the remainder of the growing season. Growth stages of the crop were determined from the number of visible leaf collars as described by Ritchie et al. (1997). Season-long weedy and weed-free controls also were included.

Prior to the V15 stage of corn, weed removal was achieved with glyphosate at $1.1 \mathrm{~kg}$ ai/ha with ammonium sulfate at $3.2 \mathrm{~kg} / \mathrm{h}$. Applications were made with a bicycle-wheel sprayer equipped with nine XR $110015^{3}$ nozzles spaced $0.5 \mathrm{~m}$ apart and calibrated to deliver a volume of $187 \mathrm{~L} / \mathrm{ha}$ at a pressure of $207 \mathrm{kPa}$. Because of crop and weed size at V15 and R1, weed removal was conducted by destroying the weed populations with a hoe at those removal times. Beginning $5 \mathrm{~d}$ after initial treatment, all subsequent emerging weeds were removed by hand or hoe on a weekly basis.

Sampling and Measurements. Soil $\mathrm{NO}_{3}-\mathrm{N}$ status was monitored throughout the growing season in the season-long weedy and weed-free controls within each $\mathrm{N}$-addition treatment. A composite of five (20-mm diameter) soil cores were taken in an " $\mathrm{X}$ " pattern from a $1.2-\mathrm{m}^{2}$ sampling area within the center of the experimental unit. Each core was divided into increments of 0 to $0.15 \mathrm{~m}$ and 0.15 to $0.30 \mathrm{~m}$ prior to mixing. Therefore, two composite samples were obtained from each experimental unit at each sampling date. Each composite was thoroughly mixed, air dried for $1 \mathrm{wk}$, crushed, screened, and submitted for nitrate analysis with the use of the cadmium reduction method (Gelderman and Beegle 1998) at the University of Nebraska Soil and Plant Analytical Laboratory. Nitrate concentrations for each sample depth were converted to a mass basis as previously described for preplant samples and summed.

Corn plants were destructively harvested at times coinciding with soil $\mathrm{NO}_{3}-\mathrm{N}$ sampling in all season-long weedy and weed-free treatments. Four or five plants from either the second or fourth row of each experimental unit in these treatments were clipped at the soil surface and dried at $70 \mathrm{C}$ to constant mass (Evans et al. 2003b). Additional harvests were obtained during mid-grain fill (R4) at HAL and at physiological maturity (R6) at both locations.

To determine total aboveground biomass and $\mathrm{N}$ content of corn shoots, corn plants were destructively harvested in all duration of weed interference treatments at anthesis (R1). Plants were clipped at the soil surface, dried at $70 \mathrm{C}$ to constant mass, ground, homogenized, and analyzed for total $\mathrm{N}$ concentration with the use of an automated LECO FP$428^{4}$ total $\mathrm{N}$ analyzer at the University of Nebraska Soil and Plant Analytical Laboratory.

At the early milk stage of the crop (R3), measurements of corn leaf greenness were made within each experimental unit with the use of a SPAD $502^{5}$ meter. Measurements were collected for all experiments except the ARDC site in 1999. Dates of data collection were August 16, 1999, at HAL and August 1 and 16, 2000, for HAL and ARDC, respectively. A sample consisted of the average readings taken from 30 consecutive corn plants within the middle of the fifth row in each experimental unit. Measurements were taken from the middle section of the leaf subtending the main ear at a point 10 to $20 \mathrm{~mm}$ from the edge of the leaf blade. Damaged or chlorotic regions of leaves were avoided as not to bias the measurements.

Data Analysis. The effect of $\mathrm{N}$ application and weed interference (season-long weedy versus weed-free) treatments on soil $\mathrm{NO}_{3}-\mathrm{N}$ were compared by sampling date with the use of ANOVA from PROC MIXED in SAS ${ }^{6}$ (Littell et al. 1996) and plotted as a function of the number of growing degree days accumulated from corn emergence (Gilmore and Rogers 1958). To quantify the dependence of corn growth on $\mathrm{N}$ supply, corn shoot mass at physiological maturity was compared among $\mathrm{N}$-addition and weed interference (seasonlong weedy versus weed-free) treatments with ANOVA, then regressed on the average daily $\mathrm{NO}_{3}-\mathrm{N}$ available $(\mathrm{kg} \mathrm{N} / \mathrm{ha} / \mathrm{d})$ throughout the growing season. Average daily $\mathrm{NO}_{3}-\mathrm{N}$ available (kg N/ha/d) was quantified by linear interpolation between soil sampling dates, integrating the area under the curve, and dividing by the total number of days in the sampling period.

To assess the effect of $\mathrm{N}$-addition and weed interference (season-long weedy versus weed-free) treatments on corn $\mathrm{N}$ nutritional status, the nitrogen nutrition index (NNI) was compared with the use of ANOVA as described above. To determine if the SPAD meter could be used as a reliable indicator of the $\mathrm{N}$ nutritional status of the corn crop, the natural logarithm of NNI (ln NNI) was regressed on the normalized SPAD index. The NNI was calculated for each experimental unit using the actual $\mathrm{N}$ concentration measured at R1 within each $\mathrm{N}$ application and duration of weed interference treatment and the $\% \mathrm{~N}_{\mathrm{c}}$ calculated from Equation 1 with the use of observed shoot biomass at R1. The NNI 

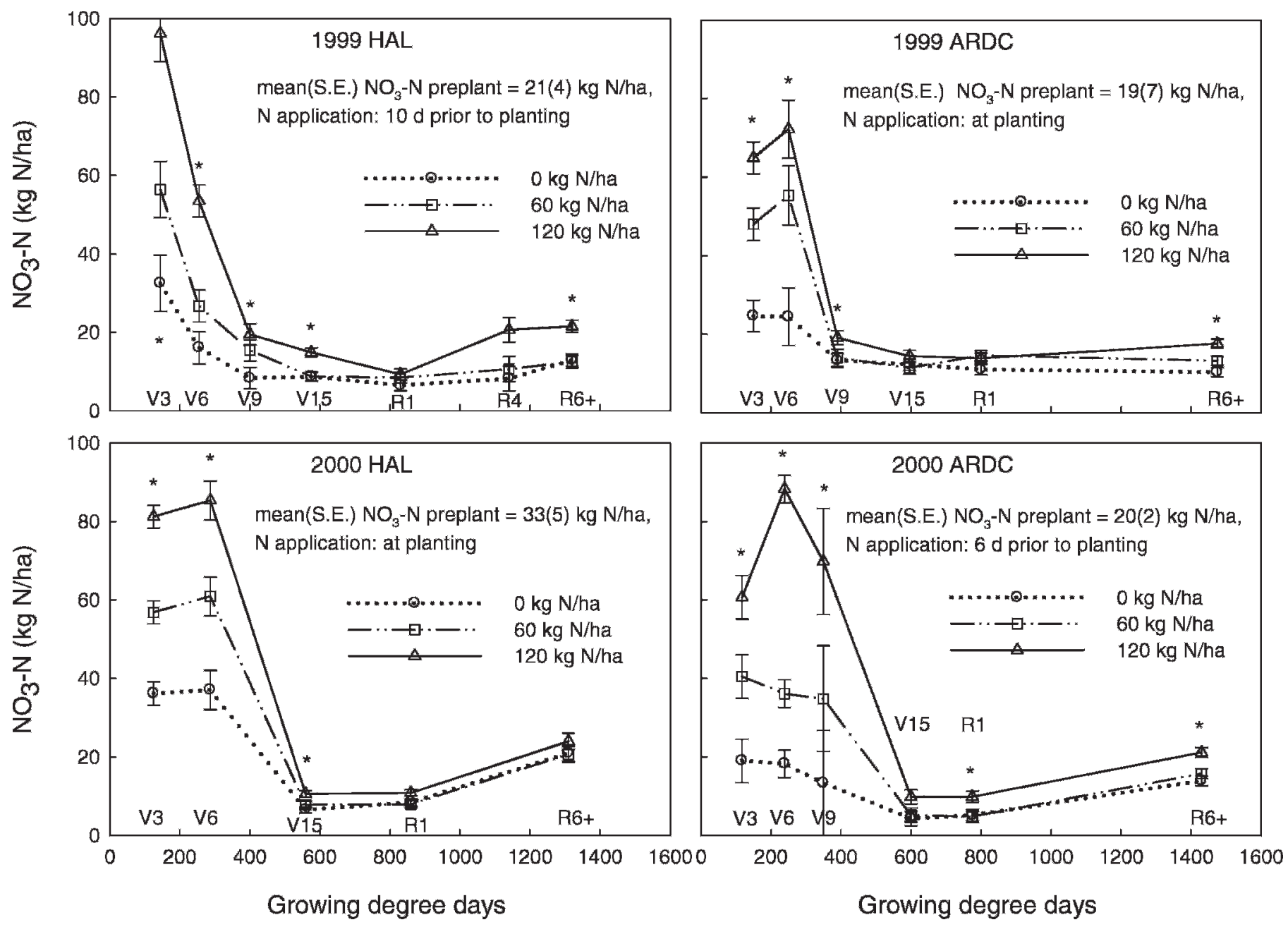

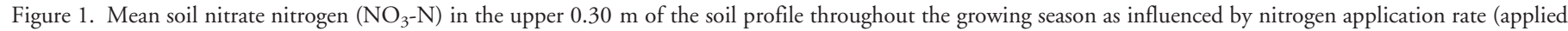

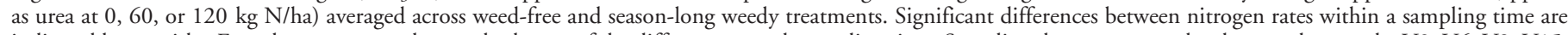

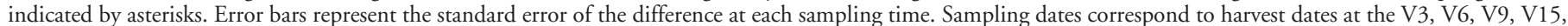
R1, and the final sample near R6. An additional sample was taken at R3 at Haskell Agricultural Laboratory in 1999.

values were $\log$ transformed to satisfy the assumption of normality. Normalized SPAD index was obtained by dividing the average SPAD reading obtained at the R3 stage of development for each experimental unit by the average SPAD reading across all experimental units within the weed-free, 120-kg N/ha $\mathrm{N}$ application treatment within a location. Slopes and intercepts of the regression of $\ln$ NNI on the normalized SPAD index were compared among $\mathrm{N}$ application and duration of weed interference treatments and found not to differ, so all data were pooled to obtain a single relationship for each location. The normalized SPAD index is assumed to be a reliable predictor of the NNI if the regression explains at least $80 \%$ of the variation in the overall mean $\ln$ NNI (i.e., $R^{2}$ $\geq 0.80$ ), and a reasonable predictor of the NNI if the $R^{2} \geq$ 0.65 .

\section{Results and Discussion}

Effects of $\mathrm{N}$ Addition and Weed Interference on Soil $\mathrm{NO}_{3}$ $\mathbf{N}$. The interaction effect of $\mathrm{N}$-addition and weed interference (season-long weedy and weed-free) treatment on soil $\mathrm{NO}_{3}-\mathrm{N}$ was not significant $(\mathrm{P}>0.10)$ when the data were analyzed by sampling time. Therefore, we evaluated the main effects of $\mathrm{N}$ treatment and weed interference treatments separately. Soil $\mathrm{NO}_{3}-\mathrm{N}$ present in the top $0.3 \mathrm{~m}$ soil was greater in the greater $\mathrm{N}$-addition treatments, especially at the beginning of the season (Figure 1). Differences in time of maximum soil $\mathrm{NO}_{3}$ $\mathrm{N}$ may be due in part to the rate of nitrification, which is temperature dependent. Soil $\mathrm{NO}_{3}-\mathrm{N}$ declined with time in all treatments in a pattern similar to that reported in Lengnick and Fox (1994) and Davis and Liebman (2001). With the exception of the $1999 \mathrm{HAL}$ site, soil $\mathrm{NO}_{3}-\mathrm{N}$ decreased most rapidly during the period between 200 and 600 growing degree days after emergence (GDD). $\mathrm{NO}_{3}-\mathrm{N}$ levels at the 1999 HAL site began to decline somewhat earlier, with the period of most rapid decline at 100 to 300 GDD. The decline in $\mathrm{NO}_{3}-\mathrm{N}$ closely corresponded with the period of greatest corn and weed biomass increase at all locations (data not shown) indicating that plant uptake was primarily responsible for the decline. Other losses due to denitrification, leaching, 

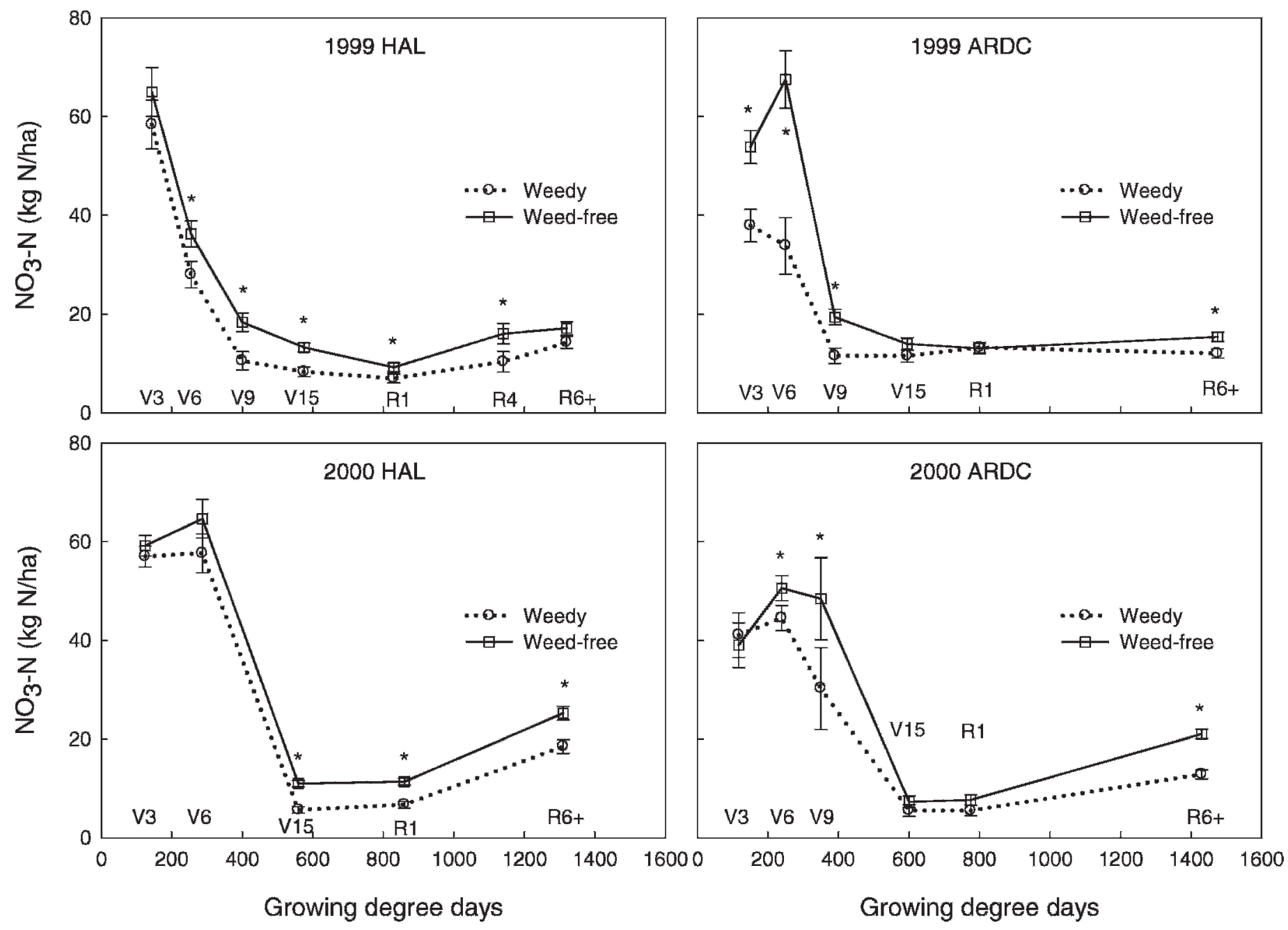

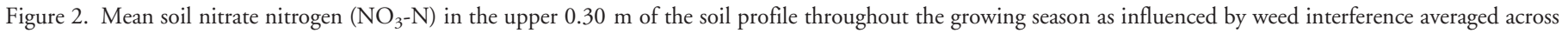

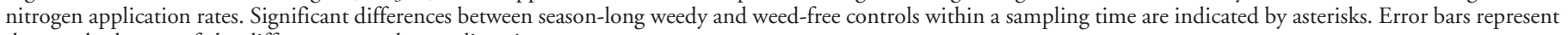
the standard error of the difference at each sampling time.

and immobilization may have occurred, but were not quantified.

The level of soil $\mathrm{NO}_{3}-\mathrm{N}$ approached a minimum of $10 \mathrm{~kg}$ $\mathrm{N} / \mathrm{ha}$ regardless of the $\mathrm{N}$ or weed interference treatment (Figures 1 and 2), and then increased slightly at the end of the season. Except for HAL 1999, there were no soil samples taken between 900 and 1,300 GDD. The sample taken at 1,140 GDD at HAL in 1999 indicated little change during the grain fill period. However, the effects of fertilization were seen at the end of the growing season at 3 of the 4 site yr (Figure 1). The slight increase in $\mathrm{NO}_{3}-\mathrm{N}$ observed postharvest (e.g., the final sample) may reflect mineralization from plant residue and $\mathrm{N}$ that was immobilized earlier in the season.

The decline in soil $\mathrm{NO}_{3}-\mathrm{N}$ over time in the season-long weedy treatment followed a similar pattern to that in corn monoculture (Figure 2). The presence of weeds reduced $\mathrm{NO}_{3}-\mathrm{N}$ compared to the weed-free corn treatment, indicating that weeds reduced the amount of $\mathrm{N}$ available to the crop for at least part of the growing season. The amount of time required before differences in soil $\mathrm{NO}_{3}-\mathrm{N}$ between seasonlong weedy and weed-free treatments were detected varied at each site and year. At the 1999 ARDC site, the presence of weeds reduced $\mathrm{NO}_{3}-\mathrm{N}$ by $50 \%$ at $26 \mathrm{~d}$ after emergence $(250$ GDD), which corresponded to the V6 growth stage of corn. At the 2000 HAL site, effects of weed interference on soil $\mathrm{NO}_{3}-\mathrm{N}$ status were not detected until approximately $57 \mathrm{~d}$ after crop emergence (595 GDD), corresponding to the V15 growth stage of corn. The delay in detection of differences at the HAL 2000 site is consistent with the delay in the beginning of the critical period for weed control (CPWC) observed for this experiment and was attributed to later weed emergence and lower weed densities at the site (Evans et al. 2003a). Similarly, differences detected early in the season at the 1999 ARDC site are attributed to a very dense weed population that emerged prior to the crop. Results of this research show that growth of both crop and weed results in depletion of $\mathrm{NO}_{3}-\mathrm{N}$ in the surface $0.3 \mathrm{~m}$ of soil. Interspecific competition for $\mathrm{NO}_{3}-\mathrm{N}$ was evident because differences in soil $\mathrm{NO}_{3}-\mathrm{N}$ between season-long weedy and weed-free 
Table 1. Corn shoot mass at physiological maturity (R6) in the season-long weedy and weed-free treatments at three levels of N supply.

\begin{tabular}{|c|c|c|c|c|c|c|c|c|}
\hline \multirow[b]{3}{*}{$\mathrm{N}$ rate } & \multicolumn{4}{|c|}{1999} & \multicolumn{4}{|c|}{2000} \\
\hline & \multicolumn{2}{|c|}{ HAL } & \multicolumn{2}{|c|}{ ARDC } & \multicolumn{2}{|c|}{ HAL } & \multicolumn{2}{|c|}{ ARDC } \\
\hline & Weedy & Weed-free & Weedy & Weed-free & Weedy & Weed-free & Weedy & Weed-free \\
\hline \multicolumn{9}{|l|}{$\mathrm{kg} \mathrm{N} / \mathrm{ha}$} \\
\hline 0 & $6.75 a^{*}$ & $11.53 \mathrm{~b}$ & $5.53 \mathrm{a}^{*}$ & $17.60 \mathrm{a}$ & $7.85 \mathrm{a}^{*}$ & $14.01 \mathrm{ab}$ & $7.41 \mathrm{a}^{*}$ & $11.93 \mathrm{~b}$ \\
\hline 60 & $8.08 \mathrm{a}^{*}$ & $13.19 \mathrm{ab}$ & $8.13 \mathrm{a}^{*}$ & $20.85 a$ & $9.01 \mathrm{a}^{*}$ & $13.31 \mathrm{~b}$ & $9.13 \mathrm{a}^{*}$ & $13.77 \mathrm{ab}$ \\
\hline 120 & $8.70 a^{*}$ & $14.94 \mathrm{a}$ & $8.31 \mathrm{a}^{*}$ & $21.47 \mathrm{a}$ & $9.61 a^{*}$ & $15.75 \mathrm{a}$ & $9.96 a^{*}$ & $15.53 \mathrm{a}$ \\
\hline SE & \multicolumn{2}{|c|}{0.822} & \multicolumn{2}{|c|}{1.743} & \multicolumn{2}{|c|}{0.576} & \multicolumn{2}{|c|}{1.141} \\
\hline
\end{tabular}

${ }^{a}$ Mean biomass followed by different letters within a column indicate differences among $\mathrm{N}$ supply treatments at $\mathrm{P}<0.05$. An asterisk next to the mean biomass of the weedy treatment indicates it differed from the weed-free treatment at $\mathrm{P}<0.05$.

${ }^{\mathrm{b}}$ Abbreviations: HAL, Haskell Agricultural Laboratory; ARDC, University of Nebraska Agricultural Research and Development Center; SE, standard error of the mean.

treatments were observed as early as 100 GDD after crop emergence (Figure 1).

Corn Shoot Mass at Physiological Maturity. Corn shoot mass at physiological maturity was always reduced in the season-long weedy treatments compared to the weed-free control (Table 1). Corn shoot mass in the season-long weedy treatments did not differ among $\mathrm{N}$-addition treatments, but shoot mass in the weed-free treatments increased with $\mathrm{N}$ addition in three of the 4 site yr. The difference in corn shoot mass among $\mathrm{N}$-addition treatments was much smaller (14 \pm $7 \%)$ than the difference in shoot mass among weed-free and season-long weedy treatments $(45 \pm 12 \%)$.

Corn shoot mass at physiological maturity was linearly related to the daily average quantity of $\mathrm{NO}_{3}-\mathrm{N}$ available $(\mathrm{kg}$ $\mathrm{N} / \mathrm{ha} / \mathrm{d}$ ) throughout the growing season (Figure 3), indicating that corn shoot biomass is at least partially dependent on $\mathrm{NO}_{3}-\mathrm{N}$ availability, regardless of $\mathrm{N}$-addition or weed interference (season-long weedy versus weed-free) treatment. The linear relationship is significant, with slopes ranging from 21 to $67 \mathrm{~g} / \mathrm{m}^{2} \mathrm{~kg}$ available $\mathrm{N} / \mathrm{ha} / \mathrm{d}$, but the coefficient of determination $\left(R^{2}\right)$ of these regressions is relatively low, indicating that $40,32,36$, and $29 \%$ of the variance in corn shoot mass can be explained by variation in $\mathrm{NO}_{3}-\mathrm{N}$ availability at HAL and the ARDC in 1999 and in 2000, respectively. Therefore, 60 to $71 \%$ of the variance in corn shoot biomass must be explained by other factors, such as competition for light, water, or other soil resources.

Corn Nitrogen Nutrition Index. A nitrogen nutrition index (NNI) of 1.0 indicates that the actual $\mathrm{N}$ concentration of the crop is equal to the critical $\mathrm{N}$ concentration, meaning that there is no $\mathrm{N}$ deficiency in crop tissues. NNI values smaller than 1.0 indicate $\mathrm{N}$ deficiency. Corn NNI measured near anthesis (R1) was always smaller in the season-long weedy treatment compared to weed-free corn (Table 2). NNI did not differ from 1.0 in any of the weed-free, $120-\mathrm{kg} \mathrm{N} / \mathrm{ha}$ treatments, but declined with declining $\mathrm{N}$ addition in all site years. The NNI in season-long weed-free treatments differed among $\mathrm{N}$-addition treatments at all locations. The difference in NNI among $\mathrm{N}$-addition treatments $(26 \pm 14 \%)$ was similar to the difference in NNI among weed interference treatments $(38 \pm 10 \%)$. Because corn shoot biomass was influenced more by weed interference than $\mathrm{N}$ addition, the effect of $\mathrm{N}$ addition appears to have a greater impact on $\mathrm{N}$ concentration in tissues than on corn biomass accumulation under weed-free conditions.

Average corn SPAD meter readings in the weed-free, 120 $\mathrm{kg} \mathrm{N} /$ ha treatment ranged from 53 to 59 (data not shown). Smeal and Zhang (1994) suggested that a SPAD meter reading of 52 was the minimum threshold for preventing corn yield loss. Therefore, it is expected that a normalized SPAD index below 1.0 will correspond to a reduced $\mathrm{N}$ nutrition index (NNI). The natural log of the NNI (ln NNI) obtained at R1 was predicted by the normalized SPAD index measured at R3 with reasonable accuracy, as all of the regression lines shown in Figure 4 have an $R^{2}$ greater than or equal to 0.65. These results were obtained for the season-long weedy, the weed-free control, as well as for the 5 duration of weed interference treatments outlined in Evans et al. (2003a). The relationship between ln NNI and normalized SPAD index did not vary among $\mathrm{N}$-addition treatments or weed interference treatments within a location, indicating that it is robust across varying $\mathrm{N}$ supply and competitive environments. The relationship also did not vary among years at the HAL location, but differed at the ARDC in 2000. These results suggest that a normalized SPAD index measured at R3 may be a useful indicator of corn $\mathrm{N}$ nutrition status. Ziadi et al. (2008b) showed a strong relationship between corn NNI and the normalized SPAD readings collected as early as V12, a time that may be more realistic for applying supplemental nitrogen to recover from $\mathrm{N}$ stress.

Weed interference had severe effects on corn biomass accumulation in this study. Variation in $\mathrm{N}$ addition resulted in greater differences in soil $\mathrm{NO}_{3}-\mathrm{N}$ early in the season compared to the effect of weed interference, but the differences were similar later in the season. Soil $\mathrm{NO}_{3}-\mathrm{N}$ declined to levels expected to cause $\mathrm{N}$ deficiency and weed interference further reduced $\mathrm{NO}_{3}-\mathrm{N}$ supply. Although $\mathrm{N}$ deficiency is expected to reduce tissue $\mathrm{N}$ concentration, corn also will reduce leaf expansion in order to maintain a minimum tissue N content (Sinclair and Horie 1989), which also reduces overall growth rate. Corn shoot biomass at physiological maturity was partially dependent on the average amount of available soil $\mathrm{NO}_{3}-\mathrm{N}$, increasing by 21 to $67 \mathrm{~g} / \mathrm{m}^{2}$ for each kilogram of available $\mathrm{NO}_{3}-\mathrm{N}$, depending on year and location. However, the fact that corn shoot biomass was much 

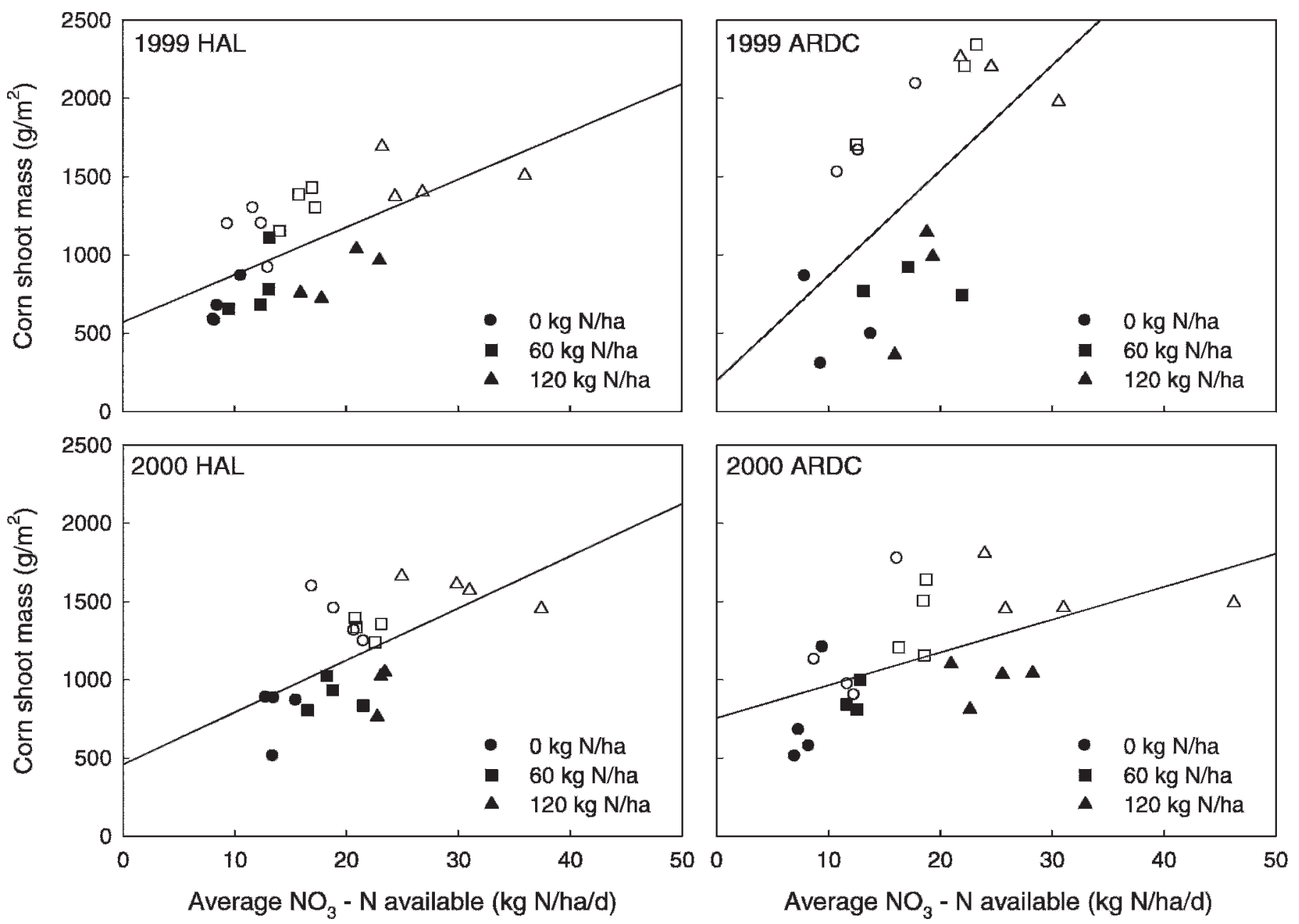

Figure 3. Corn shoot biomass $\left(W, g / \mathrm{m}^{2}\right)$ at physiological maturity in relation to average soil nitrate nitrogen $\left(\mathrm{NO}_{3}-\mathrm{N}\right)$ available $(\mathrm{kg} N /$ ha/d) throughout the growing season. Open and closed symbols represent the weed-free and season-long weedy treatments, respectively. Slope and intercept did not differ among $\mathrm{N}$-addition treatments, so a single regression line was fit to all data within a site year. Regression lines are as follows: $W=569(136)+30(7.9) \mathrm{NO}_{3}-\mathrm{N}, R^{2}=0.40, \mathrm{P}<0.0009$ at Haskell Agricultural Laboratory (HAL) in 1999; $W=196(451)+67(25) \mathrm{NO}_{3}-\mathrm{N}, R^{2}=0.32, \mathrm{P}<0.015$ at the University of Nebraska Agricultural Research and Development Center (ARDC) in 1999; $W=459(212)+33(9.7) \mathrm{NO}_{3}-\mathrm{N}, R^{2}=0.36, \mathrm{P}=0.003$ at $\mathrm{HAL}$ in $2000 ; W=756(140)+21(7.0) \mathrm{NO}_{3}-\mathrm{N}, R^{2}=0.29$, $\mathrm{P}<0.007$ at ARDC in 2000 where values in parentheses are the standard error of the estimate.

Table 2. Corn $\mathrm{NNI}^{\mathrm{a}}$ measured near anthesis (R1) in the season-long weedy and weed-free treatments at three levels of $\mathrm{N}$ supply. ${ }^{\mathrm{b}, \mathrm{c}}$

\begin{tabular}{|c|c|c|c|c|c|c|c|c|}
\hline \multirow[b]{3}{*}{$\mathrm{N}$ rate } & \multicolumn{4}{|c|}{1999} & \multicolumn{4}{|c|}{2000} \\
\hline & \multicolumn{2}{|c|}{ HAL } & \multicolumn{2}{|c|}{ ARDC } & \multicolumn{2}{|c|}{ HAL } & \multicolumn{2}{|c|}{ ARDC } \\
\hline & Weedy & Weed-free & Weedy & Weed-free & Weedy & Weed-free & Weedy & Weed-free \\
\hline \multicolumn{9}{|c|}{$\mathrm{kg} \mathrm{N} / \mathrm{ha}$} \\
\hline 0 & $0.46 b^{*}$ & $0.64 c$ & $0.43 \mathrm{a}^{*}$ & $0.83 b$ & $0.53 \mathrm{a}^{*}$ & $0.91 \mathrm{~b}$ & $0.35 c^{*}$ & $0.59 \mathrm{~b}$ \\
\hline 60 & $0.48 b^{*}$ & $0.86 \mathrm{~b}$ & $0.53 \mathrm{a}^{*}$ & $1.10 \mathrm{a}$ & $0.64 a^{*}$ & $0.84 \mathrm{~b}$ & $0.47 \mathrm{~b}^{*}$ & $0.63 \mathrm{~b}$ \\
\hline
\end{tabular}

${ }^{a} \mathrm{NNI}=\mathrm{N} \% / 3.4 W^{-0.37}$, where $\mathrm{N} \%$ is percent $\mathrm{N}$ in aboveground tissues and $W$ is the aboveground dry biomass near anthesis.

${ }^{\mathrm{b}}$ Mean NNI values followed by different letters within a column indicate differences among $\mathrm{N}$ supply treatments at $\mathrm{P}<0.05$. An asterisk next to the mean NNI of the weedy treatment indicates it differed from the weed-free treatment at $\mathrm{P}<0.05$.

cAbbreviations: NNI, nitrogen nutrition index; HAL, Haskell Agricultural Laboratory; ARDC, University of Nebraska Agricultural Research and Development Center; SE, standard error of the mean. 

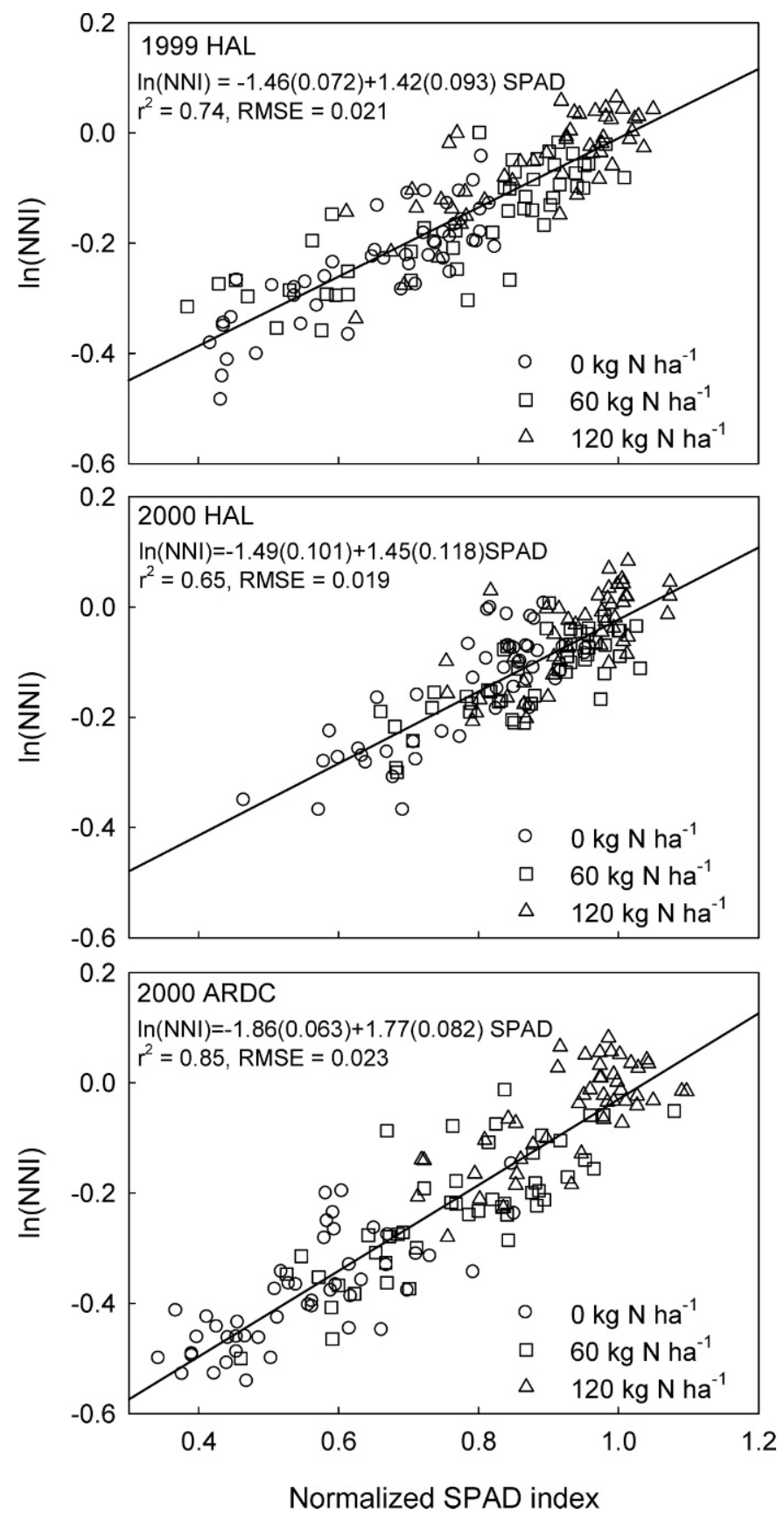

Figure 4. Natural logarithm of the nitrogen nutrition index (NNI) in relation to the normalized SPAD index. NNI $=\% \mathrm{~N}_{\mathrm{a}} / \% \mathrm{~N}_{c}$, where $\% \mathrm{~N}_{\mathrm{a}}$ and $\% \mathrm{~N}_{\mathrm{c}}$ are the actual and critical $\mathrm{N}$ concentration of corn at the R1 stage of development. Critical $\mathrm{N}$ concentration was calculated using $\% \mathrm{~N}_{\mathrm{c}}=3.4 \mathrm{~W}^{0.37}$, where $W$ was the measured corn shoot biomass $(\mathrm{Mg} / \mathrm{ha})$ within that experimental unit. The normalized SPAD index was calculated by dividing the average SPAD reading for each experimental unit by the average SPAD reading across all experimental units within the weed-free, $120-\mathrm{kg} \mathrm{N} / \mathrm{ha} \mathrm{N}$ application treatment within a location.

more affected by weed interference (an average $45 \%$ reduction) than $\mathrm{N}$-addition treatment $(<15 \%$ difference) implies that additional factors such as weed competition for light, water, or other soil resources also contributed to the reduction in corn shoot biomass.
The NNI is a useful indicator of $\mathrm{N}$ stress because it partially integrates growth and $\mathrm{N}$ concentration in tissues over the growth period (Devienne-Barret et al. 2000). The NNI was also shown to be a reliable predictor of corn relative yield (Ziadi et al. 2008b). Weed interference had a relatively small affect on soil $\mathrm{NO}_{3}-\mathrm{N}$, but a relatively large affect on NNI, primarily as the result of the large influence of weed interference on corn growth. The fact that the normalized SPAD index was able to predict NNI with reasonable accuracy is remarkable given that the SPAD meter only provides an estimate of the relative chlorophyll content of the leaves. Thus, even though weed competition for factors other than $\mathrm{N}$ may be the major contributor to corn biomass reduction in this research, use of the SPAD meter may be a useful diagnostic tool for assessing the overall negative effects of weeds on corn productivity and guide supplemental nitrogen applications, especially if utilized during the late vegetative stages of development.

\section{Sources of Materials}

${ }^{1}$ Ground-driven fertilizer drop spreader, Barber Engineering Ltd., 1404 N. Regal St., Spokane, WA 99202-3697.

2 Glyphosate-resistant corn cultivar 'DK589RR' Monsanto Inc., 800 North Lindbergh Blvd., St. Louis, MO 63167.

${ }^{3}$ XR110015 nozzles, Teejet Technologies, 1801 Business Park Dr., Springfield, IL 62703.

${ }^{4}$ Automated FP-428 total N analyzer, LECO Corporation, 3000 Lakeview Avenue, St. Joseph, MI 49085-2396.

${ }^{5}$ SPAD 502 meter, Konica Minolta Sensing, Inc., 3-91 Daisennishimachi, Sakai-ku, Sakai, Osaka, Japan.

${ }^{6}$ PROC MIXED, SAS Version 8.0, Statistical Analysis Systems Institute, SAS Campus Drive, Cary, NC 27512.

\section{Acknowledgments}

The authors thank E. Blankenship for assistance in the statistical analysis. This research is a contribution of the University of Nebraska Agricultural Research Division and was supported by the United States Department of Agriculture Hatch Act and by the State of Nebraska.

\section{Literature Cited}

Below, F. E., L. E. Christensen, A. J. Reed, and R. H. Hageman. 1981. Availability of reduced $\mathrm{N}$ and carbohydrates for ear development of maize. Plant Physiol. 68:1186-1190.

Bray, R. H. and L. T. Kurtz. 1945. Determination of total, organic and available forms of phosphorus in soils. Soil Sci. 59:39-45.

Brown, J. R. and D. D. Warncke. 1988. Recommended cation tests and measures of cation exchange capacity. Pages $15-16$ in W. C. Dahnke, ed. Recommended Chemical Soil Test Procedures for the North Central Region. NCR Publ. No. 221 (Revised). Columbia, MO: Missouri Agricultural Experiment Station.

Davis, A. S. and M. Liebman. 2001. Nitrogen source influences wild mustard growth and competitive effect on sweet corn. Weed Sci. 49:558-556.

Debaeke, P., P. Rouet, and E. Justes. 2006. Relationship between the normalized SPAD index and the nitrogen nutrition index: application to durum wheat. J. Plant Nutr. 29:75-92.

Devienne-Barret, F., E. Justes, J. M. Machet, and B. Mary. 2000. Integrated control of nitrate uptake by crop growth rate and soil nitrate availability under field conditions. Ann. Bot. 86:995-1005. 
Evans, S. P., S. Z. Knezevic, C. Shapiro, and J. L. Lindquist. 2003a. Nitrogen application influences the critical period for weed control in corn. Weed Sci. 51:408-417.

Evans, S. P., S. Z. Knezevic, C. Shapiro, and J. L. Lindquist. 2003b. Influence of nitrogen and duration of weed interference on corn growth and development. Weed Sci. 51:546-556.

Gastal, F. and G. Lemaire. 2002. N uptake and distribution in crops: an agronomical and ecophysiological perspective. J. Exp. Bot. 53:789-799.

Gelderman, R. H. and D. Beegle. 1998. Nitrate-nitrogen. Pages 17-20 in J. R. Brown, ed. Recommended chemical soil test procedures for the North Central Region. North Central Regional Research Publication No. 221 (Revised). Columbia: Missouri Agricultural Experiment Station.

Gilmore, E. C. and R. S. Rogers. 1958. Heat units as a method of measuring maturity in corn. Agron. J. 50:611-615.

Goldberg, D. E. 1990. Components of resource competition in plant communities. Pages 27-49 in J. B. Grace and D. Tilman, eds. Perspectives on Plant Competition. San Diego, CA: Academic Press.

Greenwood, E.A.N. 1976. Nitrogen stress in plants. Adv. Agron. 28:1-35.

Hanway, J. J. 1962. Corn growth and composition in relation to soil fertility: I. Growth of different plant parts and relation between leaf weight and grain yield. Agron. J. 53:145-148.

Hergert, G. W., R. B. Ferguson, and C. A. Shapiro. 1995. Fertilizer suggestions for corn. Publication No. G74-174-A. Lincoln, NE: University of Nebraska Cooperative Extension. 6 p.

Lemaire, G., ed. 1997. Diagnosis of the Nitrogen Status in Crops. Berlin: Springer-Verlag. 239 p.

Lemaire, G., M. H. Jeuffroy, and F. Gastal. 2008. Diagnosis tool for plant and crop $\mathrm{N}$ status in vegetative stage: theory and practices for crop $\mathrm{N}$ management. Eur. J. Agron. 28:614-624.

Lengnick, L. L. and R. H. Fox. 1994. Simulation by NCSWAP of seasonal nitrogen dynamics in corn: I. Soil nitrate. Agron. J. 86:167-175.

Lindquist, J. L. 2001. Mechanisms of crop loss due to weed competition. Pages 233-253 in R.K.D. Peterson and L. G. Higley, eds. Biotic Stress and Yield Loss. Boca Raton, FL: CRC Press.
Lindquist, J. L., D. C. Barker, S. Z. Knezevic, A. R. Martin, and D. T. Walters. 2007. Comparative nitrogen uptake and distribution in corn and velvetleaf (Abutilon theophrasti). Weed Sci. 55:102-110.

Littell, R. C., G. A. Milliken, W. W. Stroup, and R. D. Wolfinger. 1996. SAS ${ }^{\circledR}$ System for Mixed Models. Cary, NC: SAS Institute, Inc., 1996. 633 p.

Plenet, D. and G. Lemaire. 2000. Relationships between dynamics of nitrogen uptake and dry matter accumulation in maize crops. Determination of critical N concentration. Plant Soil 216:65-82.

Ritchie, S. W., J. J. Hanway, and G. O. Benson. 1997. How a corn plant develops. Special Report No. 48. (Revised). Ames, IA: Iowa State University of Sciences and Technology, Cooperative Extension Service. $21 \mathrm{p}$

Shainsky, L. J. and S. R. Radosevich. 1992. Mechanisms of competition between douglas-fir and red alder seedlings. Ecology 73:30-45.

Sinclair, T. R. and C. T. De Wit. 1975. Photosynthate and nitrogen requirements for seed production by various crops. Science 189:565-567.

Sinclair, T. R. and T. Horie. 1989. Leaf nitrogen, photosynthesis, and crop radiation use efficiency: a review. Crop Sci. 29:90-98.

Sinclair, T. R. and R. C. Muchow. 1995. Effect of nitrogen supply on maize yield: I. Modeling physiological responses. Agron. J. 87:632-641.

Smeal, D. and H. Zhang. 1994. Chlorophyll meter evaluation for nitrogen management in corn. Commun. Soil Sci. Plant Anal. 25:1495-1503.

Tilman, D. 1990. Mechanisms of plant competition for nutrients: The elements of a predictive theory of competition. Pages 117-141 in J. B. Grace and D. Tilman, eds. Perspectives on Plant Competition. San Diego, CA: Academic Press.

Ziadi, N., M. Brassard, G. Belanger, A. N. Cambouris, N. Tremblay, M. C. Nolin, A. Claessens, and L. E. Parent. 2008a. Critical nitrogen curve and nitrogen nutrition index for corn in eastern Canada. Agron. J. 100:271-276.

Ziadi, N., M. Brassard, G. Belanger, A. Claessens, N. Tremblay, A. N. Cambouris, M. C. Nolin, and L. E. Parent. 2008b. Chlorophyll measurements and nitrogen nutrition index for the evaluation of corn nitrogen status. Agron. J. 100:1264-1273.

Received July 2, 2009, and approved September 23, 2009. 